\title{
Catharanthus makayensis L. Allorge, Phillipson \& Razakamal. (Apocynaceae), a new species from Madagascar
}

\author{
Lucile Allorge, Peter B. Phillipson \& Richardson Razakamalala
}

\begin{abstract}
ALLORGE, L., P. B. PHILLIPSON \& R. RAZAKAMALALA (2015). Catharanthus makayensis L. Allorge, Phillipson \& Razakamal. (Apocynaceae), a new species from Madagascar. Candollea 70: 61-66. In English, English and French abstracts. DOI: http://dx.doi.org/10.15553/c2015v701a7

Catharanthus makayensis L. Allorge, Phillipson \& Razakamal. (Apocynaceae), a species new to science from Madagascar is described and illustrated. It differs from all other species in the genus by the hexagonal cross-section of its stems, and by a combination of flowering and fruiting characters. Its 5-6 $\mathrm{mm}$ long filiform sepals are clearly much narrower and longer than all other species with the exception of Catharanthus coriaceus Markgr., but the latter species is highly distinct with its pendulous fruits, as opposed to erect fruits of Catharanthus makayensis and all other species of the genus. Catharanthus makayensis and Catharanthus roseus (L.) G. Don are the only species to have a magenta, rather than white to pale yellow eye. The corolla lobes and the flower buds of Catharanthus makayensis are pure white or tinted pale pink whereas Catharanthus roseus typically has pink lobes. The relationships of the new species with the eight other species of Catharanthus G. Don are discussed and an identification key to the Malagasy species of the genus is provided.
\end{abstract}

\section{Résumé}

ALLORGE, L., P. B. PHILLIPSON \& R. RAZAKAMALALA (2015). Catharanthus makayensis L. Allorge, Phillipson \& Razakamal. (Apocynaceae), une espèce nouvelle de Madagascar. Candollea 70: 61-66. En anglais, résumé anglais et français. DOI: http://dx.doi.org/10.15553/c2015v701a7

Catharanthus makayensis L. Allorge, Phillipson \& Razakamal. (Apocynaceae), une nouvelle espèce de Madagascar, est décrite et illustrée. Elle diffère de toutes les autres espèces du genre par une tige hexagonale en coupe transversale et par une combinaison de caractères des fleurs et des fruits. Ses sépales filiformes, longs de 5-6 mm, sont nettement plus étroits et plus longs que ceux de toutes les autres espèces, à l'exception de Catharanthus coriaceus Markgr., mais cette dernière espèce est clairement distincte par ses fruits penduleux, au lieu d'érigés chez le Catharanthus makayensis et toutes les autres espèces du genre. Catharanthus makayensis et Catharanthus roseus (L.) G. Don sont les seules espèces dont la corolle ait un pourtour de la gorge magenta, alors que chez les autres espèces il est blanc ou jaune pâle. Les lobes de la corolle et le bouton de Catharanthus makayensis sont blanc pur ou teintés de rose pâle alors que Catharanthus roseus (L.) G. Don a typiquement les lobes roses. Les affinités de la nouvelle espèce avec les huit autres espèces de Catharanthus G. Don sont présentées et une clé d'identification des espèces malgaches du genre est fournie.

\section{Keywords}

APOCYNACEAE - Catharanthus - Madagascar - Makay Massif - Taxonomy

Addresses of the authors:

LA: Institut de Systématique, Évolution, et Biodiversité (UMR 7205 - CNRS MNHN EPHE UPMC), Muséum national d'Histoire naturelle, C.P. 39, rue Cuvier 57, F-75231 Paris CEDEX 05, France. E-mail: allorge@mnhn.fr

PBP: Missouri Botanical Garden, P.O. Box 299, St. Louis, MO 63166-0299 (USA) and Institut de Systématique, Évolution et Biodiversité (UMR 7205 - CNRS

MNHN UPMC EPHE), Muséum national d'Histoire naturelle, rue Cuvier 57, C.P. 39, 75231 Paris CEDEX 05, France.

RR: Missouri Botanical Garden Madagascar Research and Conservation Program, B.P. 3391, Antananarivo 101, Madagascar.

Submitted on February 13, 2015. Accepted on March 15, 2015.

Edited by M. W. Callmander 


\section{Introduction}

Catharanthus G. Don (Apocynaceae) is currently known from eight species: seven are endemic to Madagascar and one species, C. pusillus (Murray) G. Don, occurs naturally in India and Sri Lanka. It was most recently treated taxonomically for Madagascar by MARKGRAF (1976) and globally by vaN Bergen (1996). A single species, the so-called 'Rosy Periwinkle', C. roseus (L.) G. Don, has become widely distributed and well-known throughout the world since it is grown as an ornamental and has medicinal properties. It has become naturalized in many tropical countries including in Madagascar itself, where it now extends beyond its native range, a limited area of south-eastern Madagascar. Details concerning the dissemination and spread of this species as an adventive are provided by Boiteau (1972), and a useful discussion of the species and its cultivars is provided by SNoeijer (1996). The remaining species are much less well known, despite also being highly decorative, and some attempts have been made to develop hybrids with some of them for the ornamental market (see VEYret, 1974 for a review).

In Madagascar the genus is distributed throughout the country, including the subarid south-west, the humid east, and extending from sea-level to as much as $2000 \mathrm{~m}$ elevation in the mountains of the central plateau (Fig. 1), each species with a more-or-less restricted natural distribution range. In the course of an expedition to cross the hitherto almost unexplored Makay Massif in the west-central part of Madagascar undertaken by one of us (LA) in 2007, material of a possible undescribed species of Catharanthus was spotted by our colleague Mohamed Mezaga (Wendenbaum, 2011: 39). During more intensive botanical inventory of the Massif undertaken in 2010 as part of the multidisciplinary study supported by the NGO Naturevolution (Wendenbaum, 2011: 174), adequate material was collected by PBP and RR to confirm that this plant could not be accommodated in any of the known species, and after careful study we have concluded that it represents the new highly distinct species which is described in this article. Four other species are essentially confined to the upland areas of Central Madagascar: C. coriaceus Markgr. (mainly in and around the Itremo Massif, and from scattered localities in the Tampoketsa west of Antananarivo and on the inselbergs around Ambalavao); C. lanceus (Bojer ex A. DC.) Pichon (common on the Central Plateau around Antananarivo and southwards to Fianarantsoa); C. longifolius (Pichon) Pichon (mountainous areas from Andringitra to the Mandrare Bassin in the south-east) and C. ovalis Markgr. (common in the southern part of the Central Plateau and extending to the Isalo Massif in the south-west, where both the typical subsp. occurs and $C$. ovalis subsp. grandiflorus Markgr. is endemic). The diminutive $C$. scitulus (Pichon) Pichon occurs in the sub-arid south and has been recorded on low-lying sandy soils along the Mangoky River valley just to

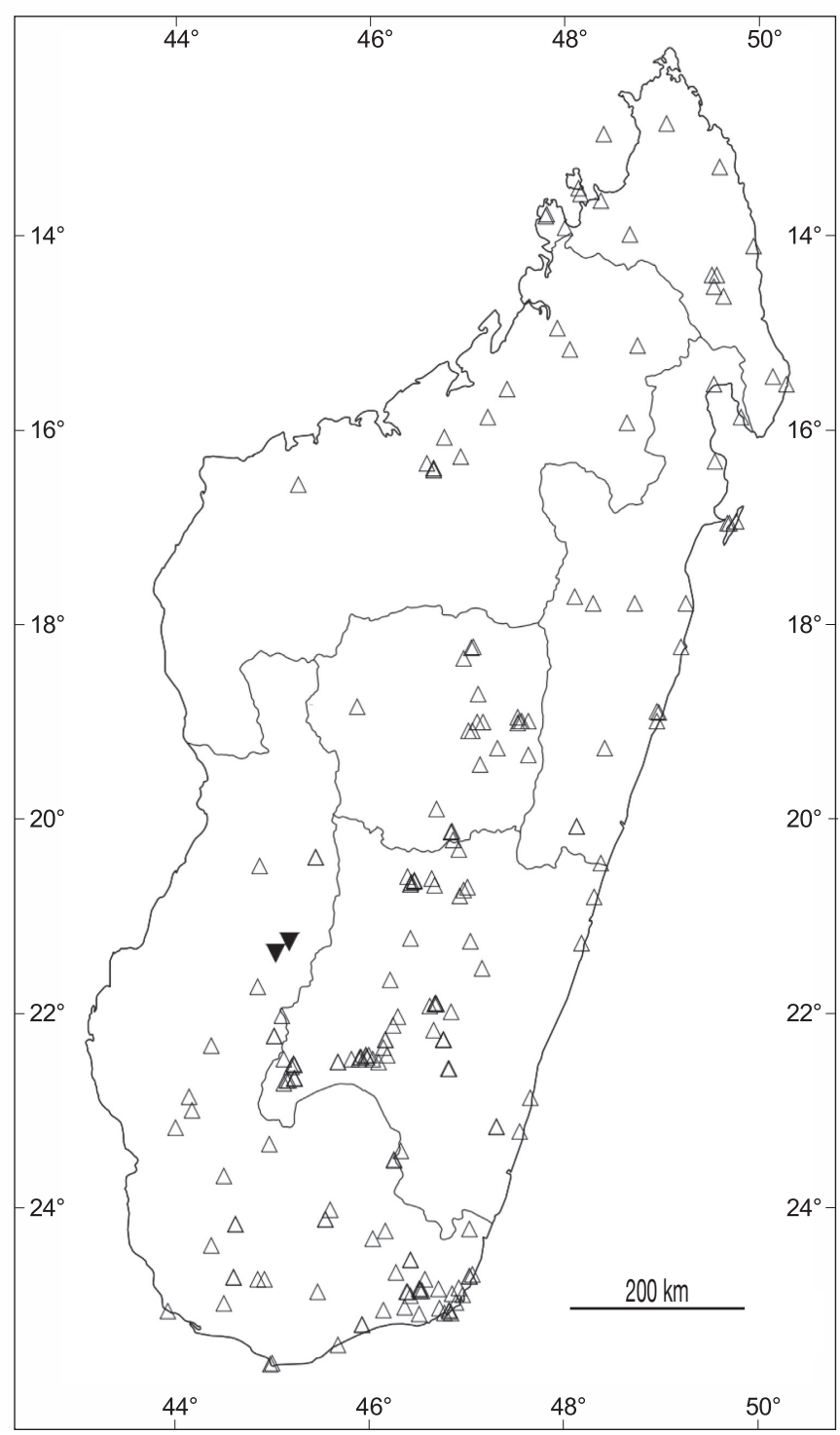

Fig. 1. - Map of Madagascar with provincial boundaries, showing the distribution of the genus Catharanthus G. Don: C. makayensis L. Allorge, Phillipson \& Razakamal. $(\boldsymbol{\nabla})$, all other species combined $(\triangle)$.

the south of the Makay Massif, but so far no other species of Catharanthus has been recorded within the massif itself. The new species is illustrated in Fig. 2A-D.

In the past, considerable difficulty seems to have been experienced in the correct identification of Catharanthus in Madagascar, and as a result much of the material seen by the authors in herbaria (notably at MO, $\mathrm{P}$ and TAN) has remained unidentified or wrongly identified. Nevertheless, we have reviewed the existing species delimitations in the light of the significant volume of material that has become available since the previous taxonomic treatments were published, and we regard them to be distinct and coherent 


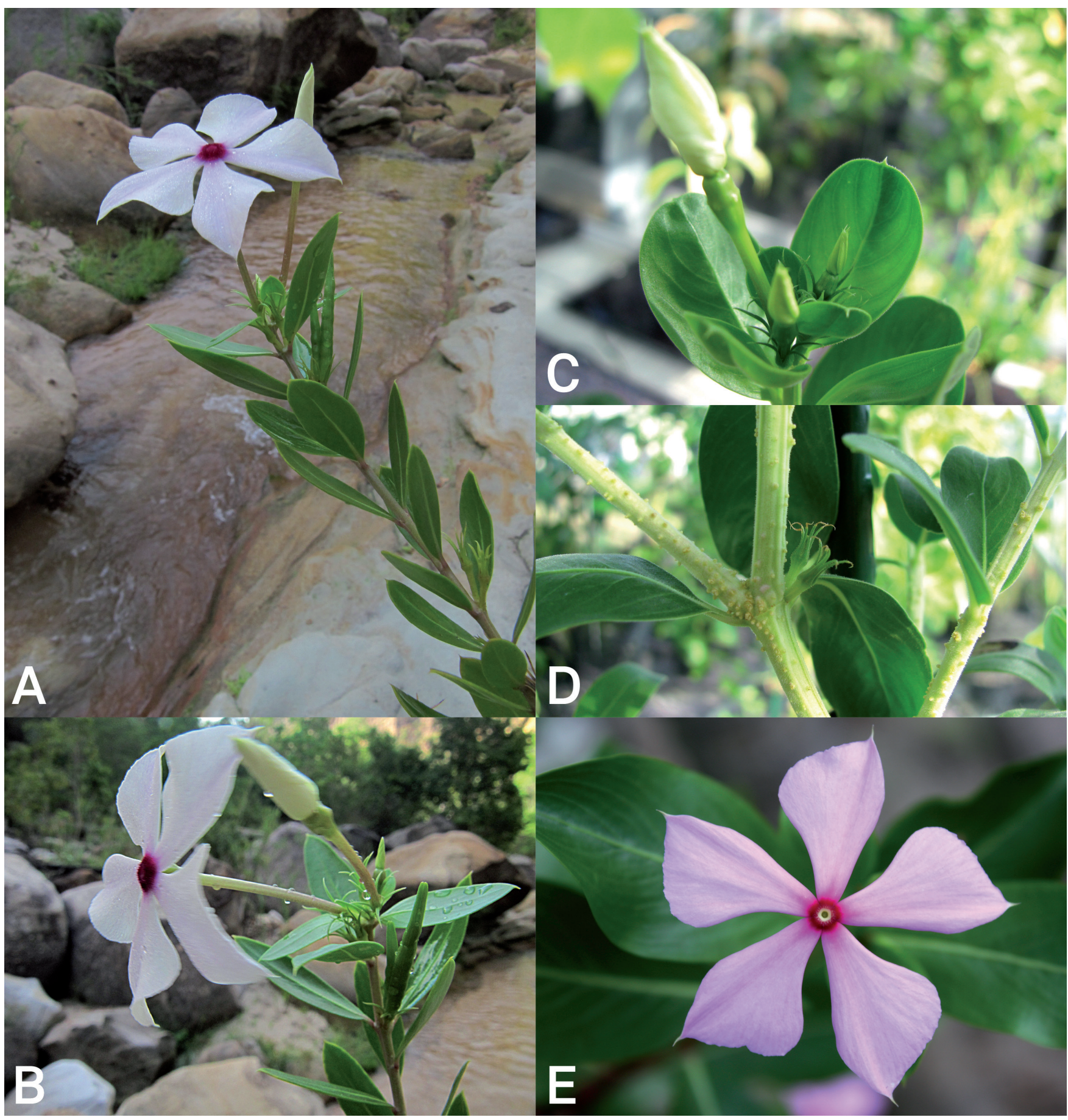

Fig. 2. - Living plants in situ of Catharanthus makayensis L. Allorge, Phillipson \& Razakamal. (A-D) and C. roseus (L.) G. Don (E).

A. Branch with inflorescence; B. Inflorescence with sideview of flower and young fruits;

C. Flower bud showing bumps in corolla tube over the stamens and stigma;

D. Detail of stems, showing the angles, petiolate leaves and persistent calices; E. Topview of flower.

[Photos: A-B: Peter Phillipson; C-D: Bruno David; E: Lucile Allorge] 
entities, albeit somewhat difficult to recognise at a glance. We therefore provide a new key to the species of Catharanthus in Madagascar, including the new species, and with the aim of providing a more reliable tool for the identification of all the species than exists at present.

\section{Identification key to the Malagasy species of Catharanthus}

1. Plants prostrate, stems spreading with pseudo-dichotomous branching, forming a rosette; flowers typically present at each node, always solitary. (Restricted to the sub-arid south)............. C. scitulus (Pichon) Pichon

1a. Plants more or less erect, stems ascending, poorlybranched, never appearing pseudo-dichotomous; flowers generally localised at the extremities of the branches, solitary or in pairs. (Widely distributed, but generally absent from the sub-arid south) $\ldots \ldots \ldots \ldots \ldots \ldots$

2. Stems clearly angular, square or hexangular in section. . 3

2a. Stems cylindrical sometimes with four shallow longitudinal

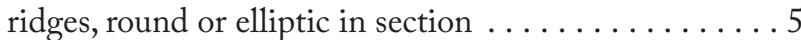

3. Leaves subsessile; stems square in section; corolla with a white to yellow eye and fuchsia pink to mauve-pink lobes. (Unknown from the Makay Massif) . . . . . . . . . . 4

3a. Leaves with petioles ca. $2 \mathrm{~mm}$ long; stems hexangular in section; corolla with a magenta eye and white (or faintly pink-tinted) lobes. (Endemic to the Makay Massif) . .C. makayensis L. Allorge, Phillipson \& Razakamal.

4. Stems and leaves glabrous; leaves oval, more or less amplexicaule at the base. (Common in the southern part of the Central Plateau and extending to the Isalo Massif and with scattered localities in the south-west) ...................... ovalis Markgr.

4a. Stems and leaves pubescent; leaves lanceolate, cuneiform at the base (throughout the northern areas of Madagascar, extending down the east coast at least as far as Farafangana) ....... C. trichophyllus (Baker) Pichon

5. Plants relatively large at maturity, at least $30 \mathrm{~cm}$ (sometimes reaching $100 \mathrm{~cm}$ ) high; leaves mostly more than $30 \mathrm{~mm}$ long; inflorescence mostly 2 -flowered; follicles always erect $\ldots \ldots \ldots \ldots \ldots \ldots \ldots \ldots \ldots \ldots \ldots \ldots$

5a. Plants relatively small at maturity, rarely more than $30 \mathrm{~cm}$ high; leaves generally less than $30 \mathrm{~mm}$ long; inflorescence 1-flowered; follicles erect or pendulous . . . . . . 7

6. Leaves ovate, generally more than $10 \mathrm{~mm}$ wide, apex obtuse and mucronate, margins flat; corolla typically pink with a magenta eye or white with a yellow eye (in $C$. roseus var. albus G. Don). (Naturally limited to the south-eastern Madagascar, but cultivated and naturalized in Madagascar, as well as throughout the tropics) . C. roseus (L.) G. Don 6a. Leaves lanceolate, less than $9 \mathrm{~mm}$ wide, apex acute, margins generally revolute; corolla pink with a yellow eye, lobes white at the very base. (Upland areas in the South-east from Andringitra to the Mandrare Bassin) . . . . . . . .............. C. longifolius (Pichon) Pichon

7. Foliage relatively dense, the leaves longer than the internodes; follicles becoming pendulous due to the elongation of the pedicels after anthesis. (Mainly in and around the Itremo Massif, but with scattered sub-populations from the Tampoketsa west of Antananarivo, and on the inselbergs around Ambalavao). . . . . . . C. coriaceus Markgr.

7a. Foliage relatively sparse, the leaves generally shorter than the internodes; follicles always erect, pedicels hardly elongating after anthesis. (Common around Antananarivo and south towards Fianarantsoa) . . ............ ............. C. lanceus (Bojer ex A. DC.) Pichon

\section{Clé d'identification des espèces malgaches de Catharanthus}

1. Plantes prostrées, tiges étalées avec ramification pseudodichotome, formant une rosette; fleurs typiquement présentes à chaque nœud, toujours solitaires. (Limitées au Sud sub-aride) .......... C. scitulus (Pichon) Pichon

1a. Plantes plus au moins dressées, tiges ascendantes, avec peu des ramifications, jamais avec un aspect pseudo-dichotome; fleurs généralement localisées dans les extrémités des branches, solitaires ou par paires. (Répandu, mais généralement absent du Sud sub-aride) . ........... 2

2. Tiges nettement angulaires, à section soit carrée soit

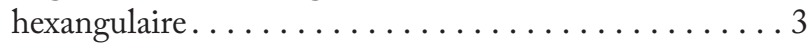

2a. Tiges cylindriques avec parfois quatre petites crêtes, à section soit ronde soit elliptique. . . . . . . . 5

3. Feuilles subsessiles; tiges à section carrée; corolle à pourtour de la gorge blanche à jaune et lobes nettement rose fuchsia à rose mauve. (Inconnu du massif du Makay)

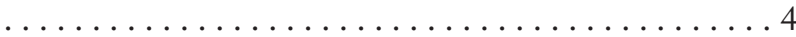

3a. Feuilles ayant un pétiole d'environ $2 \mathrm{~mm}$ de longs; tiges à section hexangulaire; corolle à pourtour de la gorge magenta et lobes blancs (à peine teintés de rose). (Endémique du massif du Makay) . . . . . . . . . . . . . . . . . . ... . C. makayensis L. Allorge, Phillipson \& Razakamal.

4. Tiges et feuilles glabres; feuilles ovales, plus ou moins amplexicaules à la base. (Fréquent dans la partie sud-est du plateau central, et sétendant au massif de l'Isalo et avec quelques localités dans le sud-ouest) . . C. ovalis Markgr.

4a. Tiges et feuilles pubescentes; feuilles lancéolées, cunéiformes à la base. (Répandu dans le nord de Madagascar, s'étendant vers le sud de la côte est jusqu'à Farafangana) ..................trichophyllus (Baker) Pichon 
5. Plantes relativement grandes à maturité, de plus de $30 \mathrm{~cm}$ de haut, pouvant atteindre $100 \mathrm{~cm}$; feuilles, pour la plupart, supérieures à $30 \mathrm{~mm}$ de long; inflorescence avec presque toujours 2 fleurs; follicules toujours dressés . . . . . . 6

$5 \mathrm{a}$. Plantes relativement petites à maturité, rarement plus hautes que $30 \mathrm{~cm}$; feuilles généralement de moins de $30 \mathrm{~mm}$ de long; inflorescence souvent à une seule fleur; follicules dressés ou pendants. . . . . . . . . . . . . 7

6. Feuilles ovées, généralement supérieures à $10 \mathrm{~mm}$ de large, apex obtus et mucroné, marges plates; corolle typiquement rose à pourtour de la gorge magenta ou blanche à pourtour de la gorge jaune (chez C. roseus var. albus G. Don). (Originaire du sud-est de Madagascar, mais cultivée et naturalisée ailleurs dans l'île, et partout dans les tropiques) .............. roseus (L.) G. Don

6a. Feuilles lancéolées, inférieures à $9 \mathrm{~mm}$ de large, apex aigu, marges généralement révolutées; corolle rose à pourtour de la gorge jaune, extrême base des lobes blancs. (Hautes terres du sud-est de Madagascar, entre le massif d'Andringitra et le bassin du Mandrare)... C. longifolius (Pichon) Pichon

7. Feuillage relativement dense, les feuilles plus longues que les entre-nœuds; follicules à terme pendants à cause des pédicelles qui s'allongent après l'anthèse. (Principalement au massif de l'Itremo et avec quelques sous-populations du Tampoketsa à l'ouest d'Antananarivo et sur les inselbergs autour d'Ambalavao) .......... C. coriaceus Markgr.

7a. Feuillage relativement épars, les feuilles généralement plus courtes que les entre-nœuds; follicules toujours dressés, les pédicelles ne s'allongeant que peu après l'anthèse. (Fréquent autour d'Antananarivo et au sud jusqu'à Fianarantsoa)........ lanceus (Bojer ex A. DC.) Pichon

Catharanthus makayensis L. Allorge, Phillipson \& Razakamal., spec. nova (Fig. 2A-D).

Typus: Madagascar. Prov. de Toliara: AtsimoAndrefana Region, Forêt d'Anosilamy, Fokontany Ber-

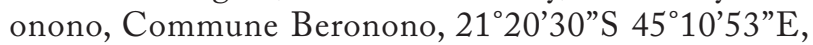
448 m, 13.I.2010, Razakamalala, Rakotovao \& Andriantiana 5155 (holo-: MO [MO-2282216]!; iso-: P, TAN!).

Differs from all other species by its hexangular stems, stems and leaves with a distinctive puberulent indument, and flowers with its long fliform recurved sepals and corolla with white lobes and a deep magenta eye.

Perennial herb to 50-60 $\mathrm{cm}$ tall, with sparse white latex. Stems hexagonal-costulate, the ridges most pronounced towards the base, puberulent at least when young, pustulate at the base; internodes ca $3 \mathrm{~cm}$ long at the base of the stem, and $2 \mathrm{~cm}$ long above. Leaves opposite; petiole $2 \mathrm{~mm}$ long; limb narrowly elliptic, $3.2-3.8 \times 1.2-1.5 \mathrm{~cm}$, mucronate, sub-coriaceous, puberulent; veins pale yellow when fresh (drying brown-green), secondary veins 6-8 sub-opposite pairs, clearly visible on the abaxial and adaxial sides, forming an angle of 30-35 to the midrib; mucro $1 \mathrm{~mm}$ long. Inflorescence pseudo-axillary, present in the axil of one leaf of a leaf-pair, usually comprising two flowers lacking a common peduncle and developing sequentially, occasionally reduced to a solitary flower. Flowers erect, shortly pedicellate; pedicels 1-2 mm long; calyx with curved filiform sepals, 5-6 mm long; corolla tube very slender, 2.8 to $3 \mathrm{~cm}$ long, $0.8 \mathrm{~mm}$ diameter, somewhat swollen in the throat 2-3 mm below the mouth, magenta; corolla propeller-like, lobes highly assymetrical, $2 \times 1 \mathrm{~cm}$, white shading abruptly to magenta at the base. Fruit comprising two erect follicles, $20 \mathrm{~mm} \times 2 \mathrm{~mm}$, containing 3-4 brown seeds.

Geographic distribution and habitat. - Catharanthus makayensis is only known from two collections made within the Makay Massif, an area of sandstone situated to the north of the Mangoky River and to the south-east of the city of Morondava. The plants were observed growing in sandy ground on riverbanks, and moist areas among rocks, at elevations of 400-600 m. The Makay region has been only very poorly explored, but recently the first serious attempts to conduct biological inventory have been made in the massif, thanks to the efforts of the NGO "Naturevolution" (http://www.naturevolution.org) and the production of a film in 2011 ("Makay, les aventuriers du monde perdu") by Gedeon Programmes (2015) and a book (Wendenbaum, 2011) about this work.

Conservation status. - Catharanthus makayensis is currently known from only two localities approximately $20 \mathrm{~km}$ apart in the Makay Massif, an area that has been only very poorly explored. Our observations in the field suggest that it is not common in the massif, although further exploration in suitable habitats would almost certainly reveal additional localities for the species. The area is remote from habitation and is currently subject to little impact from grazing or other human-induced impacts. Nevertheless the Makay Massif lacks legal protection, and proposed mining projects in the area may impact the species in the future. It is impossible to reliably estimate the Extent of Occurrence of the species on the basis of the data currently available, but based on the two known locations an estimated Area of Occupancy of ca. $8 \mathrm{~km}^{2}$ can be calculated for the species. With no immediate threats to the survival of the two known sub-populations of $C$. makayensis, and until more information on the distribution of the species becomes available it is best assessed as "Vulnerable" [VU D2] following IUCN Red List Categories and Criteria (IUCN, 2012).

Phenology. - Catharanthus makayensis has been observed in flower and in fruit in August, November and January. 
Note. - Catharanthus makayensis differs from all other species by its stems which are distinctly hexagonal in crosssection, a characteristic which is most easily observed in fresh material. Other species of Catharanthus are either quadrangular-winged in C. ovalis and C. trichophyllus, or cylindrical (sometimes with shallow longitudinal ridges) in all the other species. The new species can also be distinguished from other species of the genus by certain characters of the flowers, notably by its 5-6 $\mathrm{mm}$ long filiform sepals which are clearly much narrower and longer than for all the other species, with the only exception of $C$. coriaceus, but the latter species is highly distinct with its pendulous fruits, as opposed to the erect fruits of C. makayensis and all other species. Together with $C$. roseus, $C$. makayensis is the only species to have a magenta eye, rather than white to pale yellow in all the other species, however, the corolla lobes and the flower bud of $C$. makayensis are pure white (or possibly slightly pale pink tinted) (Fig. 2A, D) and C. roseus typically has pink lobes (Fig. 2E). Certain forms of C. roseus have a predominantly white corolla, but this is coupled with a white or pale yellow eye as far as is known in wild populations (C. roseus var. albus). Horticultural forms of $C$. roseus are available with a diversity of colours, including some that closely resemble $C$. makayensis. Two other species of Catharanthus have been collected just to the south and/or north of the Makay Massif: C. ovalis Markgr. and $C$. scitulus (Pichon) Pichon, but they have not yet been recorded within the massif itself.

Paratypi. - Madagascar. Prov. de Toliara: Atsimo-Andrefana Region. Makay Massif. Along a tributary of Menampandaha River, 21 $12^{\circ} 56^{\prime \prime S}$ 4519'07”E, 480 m, 22.XI.2010, Phillipson, Andriantiana \& Rakotovao 6174 (TAN).

\section{Acknowledgements}

We are grateful to the following people who have helped to make this work possible: Evrard Wendenbaum (the founder of Naturevolution), Mohamed Mezaga, Bruno David and the herbarium staff at MO, P and TAN, and we also thank David Middleton, Martin Callmander and Laurent Gautier for their careful reviews of the original version of this article and their suggested improvements.

\section{Reference}

Bergen, M. A. van (1996). Revision of Catharanthus G. Don. Series of Revisions of Apocynaceae-XLI. Wageningen Agric. Univ. Pap. 96: 9-46.

Boiteau, P. (1972). Sur la première mention imprimée et le premier échantillon de Catharanthus roseus (L.) G. Don. Adansonia ser. 2, 12: 129-135.

Gedeon Programmes (2015). Makay, les aventuriers du monde perdu [http://www.gedeonprogrammes.com].

IUCN (2012). IUCN Red List Categories and Criteria: Version 3.1. $2^{\text {nd }}$ Edition. IUCN Species Survival Commission, Gland \& Cambridge.

Markgraf, F. (1976). Apocynacées. In: Leroy, J.-F. (ed.), Fl. Madagascar Comores 169.

Snoeijer, W. (1996) Catharanthus roseus, the Madagascar periwinkle, a review of its cultivars. Wageningen Agric. Univ. Pap. 96: 47-120.

Veyret, Y. (1974). Quelques données pour la biosystématique de pervenches malgaches (genre Catharanthus G. Don, Apocynaceae). Candollea 29: 297-307.

Wendenbaum, E. (2011). Makay - À la découverte du Dernier Eden. Éditions de la Martinière, Paris. 